\title{
Pengelompokan Klon-Klon Ubi Jalar Berdasarkan Analisis Gerombol, Komponen Utama dan Biplot dari Karakter Morfologi
}

\author{
Grouping of Sweet Potato Clones Based on Cluster, Principal \\ Components and Biplot Analyses of Morphological Characters
}

\author{
Helen Hetharie*, Simon Hadi Teguh Raharjo, dan Edizon Jambormias
}

Jurusan Budidaya Pertanian, Fakultas Pertanian, Universitas Pattimura

Jl. Ir. M. Putuhena Kampus Poka Ambon 97233, Indonesia

Diterima 1 Oktober 2017/Disetujui 9 November 2018

\begin{abstract}
Sweet potato is a food crop with high genetic and phenotypic diversities. The objective of this study was to cluster sweet potato clones based on their morphological characters. This research used descriptive method using 25 morphological characters on 28 sweet potato clones and clustered using dice coefficient, principal component analysis and biplot analysis. The results showed that the clones were grouped into two clusters and 14 sub-clusters. Three sub-clusters had high similarity coefficients, i.e., 0.68-0.96, one clone was eliminated, and 11 sub-clusters had a low similarity, i.e., 0.41-0.52. The principal component analysis showed 14 of 25 morphological characters determined the diversity in 27 sweet potato clones with cumulative variance of $70.79 \%$. Biplot analysis showed that 12 characters contributed to cumulative variance of $61.3 \%$. Twelve morphological characters had weak contribution on the characteristics of the clones in quadrant I; meanwhile, characteristics of clones in quadrant II were orange, yellow and white tuber flesh, in quadrant III was dark purple tuber flesh, and in quadrant IV were purple tuber flesh and cortex. Result of the grouping analysis identified clones that were closely related and those distantly related for improvement purposes.
\end{abstract}

Keywords: Ipomoea batatas, cumulative variance, Maluku province, morphology, relationship

\section{ABSTRAK}

Ubi jalar merupakan tanaman pangan dengan keragaman genetik dan fenotip yang tinggi. Penelitian ini bertujuan mengelompokan klon ubi jalar berdasarkan kemiripan karakter morfologi. Penelitian menggunakan metode diskriptif dengan 25 karakter morfologi sesuai deskriptor pada 28 klon ubi jalar. Analisis data meliputi analisis gerombol menggunakan koefisien Dice, analisis komponen utama dan biplot. Hasil analisis gerombol menunjukkan klon-klon ubi jalar berkelompok dalam dua gerombol dan $14 \mathrm{sub}$ gerombol. Tiga sub gerombol dengan koefisien kemiripan tertinggi yaitu 0.68-0.96 sehingga satu klon dieliminasi, dan 11 sub gerombol dengan koefisien kemiripan yang rendah yaitu 0.41-0.52. Hasil analisis komponen utama menunjukkan 14 karakter morfologi menentukan keragaman pada 27 klon ubi jalar dengan keragaman kumulatif 70.79\%. Hasil analisis biplot didapatkan 12 karakter berkontribusi terhadap keragaman kumulatif sebesar 61.30\%. Dua belas karakter berpengaruh lemah terhadap klon-klon ubi jalar pada kuadran I, sedangkan karakteristik kelompok klon pada kuadran II yaitu daging umbi berwarna oranye, kuning dan putih, pada kuadran III daging umbi berwarna ungu tua, dan pada kuadran IV daging umbi dan korteks berwarna ungu. Hasil dari analisis pengelompokan teridentifikasi klon-klon ubi jalar yang berkerabat dekat dan berkerabat jauh untuk tujuan perbaikan.

Kata kunci: Ipomoea batatas, kekerabatan, keragaman kumulatif, morfologi, Provinsi Maluku

\section{PENDAHULUAN}

Ubi jalar (Ipomoea batatas (L) Lam) mempunyai keragaman fenotipik yang tinggi karena secara genetik

\footnotetext{
* Penulis untuk korespondensi. e-mail: helen_hetharie@yahoo.
} com tanaman ini mempunyai jumlah kromosom cukup banyak $(2 n=6 x=90)$, dan menyerbuk silang. Eksplorasi keragaman dan potensi genetik ubi jalar di Provinsi Maluku belum banyak dilakukan. Penelitian eksplorasi dan karakterisasi in situ terhadap ubi jalar di Kabupaten Seram Bagian Barat telah terkoleksi berbagai klon yang beragam pada morfologi daun, batang dan umbi (Raharjo et al., 2014). Karakterisasi morfologi pada tanaman hasil koleksi diikuti dengan analisis 
gerombol bertujuan untuk mendeteksi dan mengeliminasi duplikasi serta mendapatkan data base keragaman sebagai tahap awal dalam program pemuliaan.

Karakter-karakter yang berkontribusi terhadap keragaman suatu plasma nutfah diperlukan untuk memperkaya informasi pada data base. Analisis komponen utama dapat digunakan untuk mendapatkan variabelvariabel yang berpengaruh terhadap keragaman. Undang et al. (2015) mendapatkan 16 dari 23 karakter tanaman cabe tereduksi dalam dua komponen utama dengan keragaman kumulatif $80.51 \%$. Afuape et al. (2011) mendapatkan tiga komponen utama menyumbangkan keragaman kumulatif $76 \%$, dan karakter-karakter pada komponen utama berpengaruh besar terhadap fenotip ubi jalar.

Satu kelebihan analisis biplot yaitu dapat mengelompokkan objek berdasarkan karakteristik tertentu. Aghaee et al. (2010) membuktikan bahwa biplot merupakan suatu alat analisis yang dapat mengelompokkan karakter, serta mendiskriminasi aksesi-aksesi gandum durum yang diuji. Dengan demikian tujuan penelitian ini yaitu mendapatkan klon-klon ubi jalar yang bergerombol berdasarkan kemiripan morfologi.

\section{BAHAN DAN METODE}

\section{Bahan Tanaman dan Penanaman di Kebun Koleksi}

Penelitian dilakukan di desa Poka Kecamatan Teluk Ambon tahun 2017 terhadap 28 klon ubi jalar yang terdiri atas 26 klon ubi jalar berasal dari beberapa kabupaten di Provinsi Maluku (Tabel 1), serta 2 varietas unggul (Cilembu dan Antin 2) diperoleh dari Balitkabi Malang. Ubi jalar ditanam dengan 3 setek pucuk per polybag dengan ukuran polybag $30 \times 30 \mathrm{~cm}$, dan tiap klon diwakili oleh 2 polybag sebagai ulangan. Pemeliharaan meliputi pemberian pupuk NPK (16:16:16) 6 g per polybag (pot) untuk dua kali pemberian yaitu saat tanam dan 2 bulan setelah tanam, penyiraman pada sore hari dan penyiangan. Pot-pot diatur pada kebun koleksi dengan jarak antar pot 50 x $30 \mathrm{~cm}$.

\section{Karakterisasi Morfologi Tajuk dan Umbi Berdasarkan Deskriptor}

Pada umur 3 bulan dilakukan karakterisasi morfologi tajuk, dan pada umur 5 bulan karakterisasi terhadap morfologi umbi. Karakterisasi dilakukan pada tanaman di polybag pertama, kemudian diverifikasi pada polybag kedua. Karakterisasi morfologi berdasarkan deskriptor ubi jalar (CIP/AVRDC/IBPGR, 1991), meliputi bentuk daun, pola lekuk daun, jumlah cuping daun, bentuk bagian tengah daun, warna tulang daun permukaan bawah dan atas, warna helaian daun muda dan dewasa, warna tangkai daun muda dan dewasa, karakter membelit, tipe tanaman, pigmentasi utama pada batang, warna sekunder batang, intensitas rambut pada ujung batang, bentuk umbi, warna dan intensitas warna kulit umbi, warna sekunder kulit umbi, warna daging umbi yang berkaitan dengan antosianin, dan $\beta$-karoten, intensitas warna daging, distribusi pigmen pada daging, warna sekunder daging, serta warna korteks.

\section{Analisis Gerombol}

Dua puluh lima karakter morfologi dari 28 klon ubi jalar dijadikan peubah biner menggunakan program microsoft excel dan minitab. Data biner selanjutnya dianalisis dengan metode agglomeration hierarchical clustering dan pengukuran kemiripan berdasarkan koefisien Dice menggunakan program SPSS versi 20.

\section{Analisis Komponen Utama dan Biplot}

Analisis komponen utama terhadap data skoring dari 25 karakter morfologi dilakukan dalam dua tahap menggunakan program SPSS versi 20. Tahap pertama, bertujuan mendapatkan variabel-variabel yang menunjukkan nilai MSA-KMO (Measures of Sampling Adequacy) > 0.5, karena variabel tersebut cukup dan layak untuk dianalisis, dan tahap kedua untuk mendapatkan jumlah komponen utama dari variabel-variabel hasil tahap pertama. Analisis

Tabel 1. Klon ubi jalar dari beberapa kabupaten di Provinsi Maluku

\begin{tabular}{llccll}
\hline Nama klon & \multicolumn{1}{c}{ Kabupaten } & Nama klon & Kabupaten & Nama klon & \multicolumn{1}{c}{ Kabupaten } \\
\hline A6 & Kota Ambon & B9 & SBB & BR2 & Buru Selatan \\
A7 & Kota Ambon & B33 & SBB & BR5 & Buru Selatan \\
A13 & Kota Ambon & B39 & SBB & BSepa-U & Maluku Tengah \\
A15 & Kota Ambon & B43 & SBB & H1 & Kota Ambon \\
AHT-U & Kota Ambon & B44 & SBB & TL1 & Maluku Tenggara \\
AR1 & Seram Bagian Barat (SBB) & B65 & SBB & TL8 & Maluku Tenggara \\
AR6 & SBB & B70 & SBB & LR2 & Maluku Tenggara Barat \\
B3 & SBB & B82 & SBB & M3 & Maluku Barat Daya \\
B5 & SBB & B102 & SBB & & \\
\hline
\end{tabular}


biplot menggunakan program Minitab 17 untuk memetakan klon ubi jalar berdasarkan variabel terpilih.

\section{HASIL DAN PEMBAHASAN}

\section{Klon-Klon Ubi Jalar Bergerombol Berdasarkan Kemiripan Karakter}

Hasil analisis gerombol didapatkan klon-klon ubi jalar berkelompok atas dua gerombol, dan 14 sub gerombol. Gerombol I terdiri dari 13 klon yang berkelompok dalam 6 sub gerombol dengan garis dendrogram terpendek pada sub gerombol I.1 dan I.4. Gerombol II terdiri dari 15 klon berkelompok dalam 8 sub gerombol, dan garis dendrogram terpendek pada klon B44 dan BR2. Garis-garis dendrogram pada Gambar 1 dengan angka standar 1-25 merupakan visualisasi dari hasil skala-kembali (rescaled distance) nilai koefisien Dice. Garis dendrogram semakin mendekati angka 0 menunjukkan hubungan kekerabatan klon-klon dalam kelompok tersebut semakin dekat, dan jika garis dendrogram semakin jauh dari angka 0 menunjukkan semakin jauh hubungan kekerabatan.

Hasil analisis gerombol dengan koefisien Dice didapatkan tingkat kemiripan klon- klon ubi jalar antara 0.41-0.96. Kemiripan tertinggi atau hubungan kekerabatan yang dekat diperlihatkan oleh klon ubi jalar pada sub gerombol I.1, I.2, dan I.4 (Gambar 1) karena mempunyai banyak karakter yang mirip dibandingkan dengan klon pada sub gerombol yang lain. Kelompok klon pada sub-sub gerombol I.1 (B82 \& TL8) mempunyai koefisien kemiripan 0.96 atau ketidakmiripan hanya $4 \%$, yang menunjukkan adanya duplikasi sehingga salah satu klon tidak diikutkan dalam analisis selanjutnya. Tairo et al. (2008) dan Maquia et al. (2013) dengan analisis gerombol menemukan aksesiaksesi ubi jalar dengan nama berbeda dan berasal dari daerah berbeda namun identik secara morfologi dan/atau genetik sebagai indikasi adanya duplikasi. Duplikasi ubi jalar ditemukan di New Guinea karena adanya pertukaran tanaman antara daerah yang jauh yaitu antara dataran tinggi dan dataran rendah (Roullier et al., 2013). Semakin banyak karakter yang mirip antar klon ubi jalar yang diteliti maka tidak akan terjadi banyak perbaikan jika dilakukan persilangan.

Tabel 2 menunjukkan sub gerombol dengan kemiripan yang terrendah yaitu I.3, II.3 II.4, II.6 dan II.8 dengan koefisien antara 0.41-0.47 atau menunjukkan ketidakmiripan tinggi yaitu $>50 \%$, dan tiap sub gerombol ini terdiri dari hanya satu klon. Sedangkan sub gerombol I.6, II.1, II.2, satu sub-sub gerombol II.5 (B102 \& B43), dan dua sub-sub gerombol II.7 (B3 \& B39 dan B3 \& B44) menunjukkan koefisien kemiripan yang cukup rendah yaitu 0.50-0.52. Hasil ini menunjukkan bahwa sebagian besar klon ubi jalar ini mempunyai banyak ketidakmiripan yang menggambarkan suatu hubungan kekerabatan yang jauh. Laurie et al. (2013) melakukan analisis gerombol berdasarkan ketidakmiripan didapatkan 57 aksesi ubi jalar bergerombol atas tiga kelompok dan bergerombolnya aksesi tersebut tidak berkaitan dengan lokasi koleksi.

Hasil analisis gerombol didapatkan juga bahwa klon lokal seperti TL1 dan M3 berada pada sub gerombol yang sama dengan varietas Antin 2 (Gambar 1). Demikian juga, varietas unggul Cilembu berada pada sub gerombol

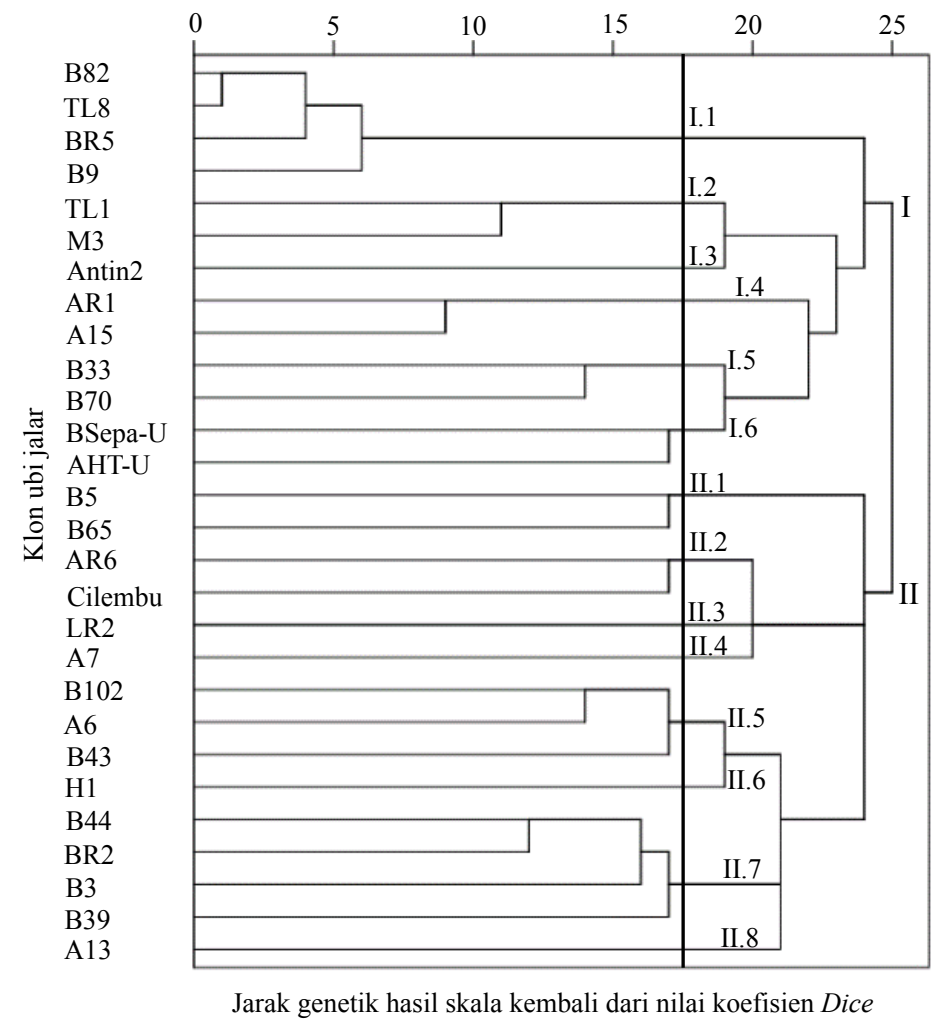

Gambar 1. Dendrogram 28 klon ubi jalar berdasarkan 25 karakter morfologi. Dendrogram ini merupakan hasil visualisasi skala kembali dari nilai koefisien Dice 
yang sama dengan klon AR6 dengan koefisien kemiripan 0.52 atau ketidakmiripan $48 \%$ (Tabel 2). Ketidakmiripan morfologi kedua klon ini terutama pada karakter umbi. Varietas Cilembu mempunyai bentuk umbi elip panjang dan warna daging umbi kuning, sedangkan umbi pada klon AR6 berbentuk panjang tidak beraturan dan daging umbi berwarna oranye. Klon-klon ubi jalar yang menunjukkan ketidakmiripan dapat menjadi tetua dalam persilangan untuk mendapatkan keragaman baru, terutama pada karakterkarakter penting seperti bentuk umbi dan warna daging umbi. Hasil penelitian Moulin et al. (2012) pada beberapa karakter umbi menunjukkan bahwa karakter bentuk umbi lebih beragam dibandingkan karakter warna daging umbi diantara aksesi ubi jalar.

\section{Analisis Komponen Utama}

Berdasarkan hasil analisis gerombol maka klon B82 dieliminasi karena mirip dengan klon TL8. Hasil analisis komponen utama terhadap 27 klon ubi jalar berdasarkan 25 karakter dan diperoleh hanya 14 karakter yang mempunyai nilai MSA-KMO > 0.5 dan uji Bartlett dengan peluang 0.000 (data tidak ditampilkan). Analisis komponen utama menjadi penting karena hasil analisis dapat dipakai untuk menentukan karakter-karakter yang berkontribusi terhadap keragaman.
Hasil analisis komponen utama terhadap 14 karakter morfologi dari 27 klon ubi jalar didapatkan tiga komponen utama yang menentukan keragaman, ditunjukkan melalui akar ciri $>1$ (Tabel 3). Komponen utama 1 (KU1), KU2, dan KU3 berkontribusi terhadap keragaman secara berurut $28.61 \%, 25.00 \%$, $17.17 \%$, dengan keragaman kumulatif mencapai $70.79 \%$ (Tabel 3). Karakter karakter pada komponen utama itulah yang menentukan keragaman ubi jalar yang diteliti. Beberapa peneliti melakukan analisis komponen utama pada ubi jalar memperlihatkan juga sejumlah karakter tereduksi kedalam beberapa komponen utama seperti Su et al. (2016) menganalisis 16 karakter tereduksi dalam lima komponen utama dengan keragaman kumulatif sebesar 66\%, Laurie et al. (2013) mendapatkan enam komponen dari 29 karakter dengan keragaman kumulatif 58\%, dan Afuape et al. (2011) mendapatkan tiga komponen utama dari 17 karakter dengan keragaman kumulatif sebesar $76 \%$.

Hasil analisis pada Tabel 4 menunjukkan bahwa 14 karakter morfologi menentukan keragaman pada klon-klon ubi jalar lokal, yang ditunjukkan melalui vektor ciri $>0.5$. Karakter-karakter yang berkelompok pada KU1 merupakan penentu utama pertama terhadap keragaman dari 27 klon yang diuji yaitu warna tulang daun pada permukaan bawah dan atas, warna tangkai dan warna helaian daun dewasa, pigmentasi pada batang utama, dan warna korteks umbi

Tabel 2. Koefisien kemiripan 28 klon ubi jalar berdasarkan koefisien Dice

\begin{tabular}{lclc}
\hline Gerombol & Sub gerombol & \multicolumn{1}{c}{ Klon ubi jalar } & Koefisien kemiripan \\
\hline \multirow{2}{*}{ I } & I.1 & B82,TL8, BR5, B9 & $0.80-0.96$ \\
& I.2 & TL1 \& M3 & 0.68 \\
& I.3 & Antin 2 (TL1) & 0.46 \\
& I.4 & AR1 \& A15 & 0.72 \\
& I.5 & B33 \& B70 & 0.6 \\
I.6 & BSepa-U \& AHT-U & 0.52 \\
II.1 & B5 \& B65 & 0.52 \\
& II.2 & AR6 \& Cilembu & 0.52 \\
II.3 & LR2 (AR6) & 0.44 \\
II.4 & A7 (AR6) & 0.43 \\
II.5 & B102, A6, \& B43 & $0.50-0.60$ \\
& II.6 & H1 (B43) & 0.47 \\
& II.7 & B44, BR2, B3 \& B39 & $0.51-0.64$ \\
\end{tabular}

Tabel 3. Akar ciri dari 14 karakter yang tereduksi dalam tiga komponen utama

\begin{tabular}{lcccccc}
\hline \multirow{2}{*}{ Komponen } & \multicolumn{3}{c}{ Akar ciri (Eigen value) } & \multicolumn{2}{c}{ Jumlah komponen utama hasil ekstrasi } \\
\cline { 2 - 7 } & Total & \% Keragaman & Kumulatif \% & Total & \% Keragaman & Kumulatif \% \\
\hline 1 & 4.006 & 28.613 & 28.613 & 4.006 & 28.613 & 28.613 \\
2 & 3.500 & 25.002 & 53.614 & 3.500 & 25.002 & 53.614 \\
3 & 2.404 & 17.171 & 70.785 & 2.404 & 17.171 & 70.785 \\
\hline
\end{tabular}


(Tabel 4). Empat karakter morfologi umbi pada KU2 adalah karakter penentu utama kedua yang menyumbangkan 25\% (Tabel 3) terhadap keragaman, dan karakter-karakter pada KU3 (Tabel 4) menyumbangkan keragaman 17.17\%. Karakter morfologi pada KU1 dan KU2 berkontribusi lebih besar terhadap keragaman ubi jalar yang diuji, dan karakterkarakter tersebut merupakan karakter kualitatif yang dapat digunakan dalam seleksi. Karakter-karakter pada KU1 dalam penelitian ini, selaras dengan yang dinyatakan oleh Yada et al. (2010) bahwa komponen utama pertama biasanya dihubungkan dengan pigmentasi seperti pigmentasi pada tangkai daun, tulang daun bagian bawah, warna daun dewasa dan daun muda.

\section{Analisis Biplot}

Hasil analisis biplot terhadap 14 karakter morfologi menunjukkan total keragaman dari dua komponen utama sebesar 53.4\%, serta didapatkan dua karakter yang mempunyai garis vektor pendek dari titik asal yaitu tipe tanaman (SifatBt2) dan intensitas rambut pada batang (SifatBt7) (Gambar 2A). Jika dua karakter tersebut dieliminasi keragaman kumulatif meningkat menjadi 61.3\% yaitu komponen utama pertama berkontribusi terhadap keragaman sebesar $32.9 \%$ dan komponen kedua sebesar 28.4\% (Gambar 2B). Hasil analisis biplot pada gandum durum juga menunjukkan jumlah buku dan klorofil kurang berkontribusi terhadap keragaman melalui garis vektor yang pendek (Aghaee et al., 2010). Dengan demikian, analisis biplot dapat menunjukkan karakter-karakter yang kurang berkontribusi terhadap keragaman melalui ukuran garis vektor yang pendek dari titik asal. Analisis komponen utama diikuti analisis biplot dapat digunakan sebagai alat seleksi keragaman untuk perbaikan suatu varietas. Koij et al. (2015) menggunakan analisis komponen utama dan biplot pada 45 galur white bean, didapatkan karakter penting untuk seleksi yaitu hasil biji, biomasa, jumlah biji per polong dan diameter batang.

Analisis biplot juga mengelompokkan klon atau varietas berdasarkan karakteristik tertentu sebagai penciri kelompok tersebut. Pada kuadran I Gambar 2B, 12 karakter (variabel) berpengaruh lemah terhadap karakteristik morfologi klon AR1, A15, B33 dan B70 karena kelompok ini pada posisi tidak searah atau berlawanan dengan semua garis vektor. Sedangkan 12 klon pada kuadran II menunjukkan karakteristik yang kuat pada warna daging umbi yang berkaitan dengan $\beta$-karoten (SifatUb7), tulang daun bagian atas (sifatDn5) dan bawah (SifatDn6) berwarna ungu parsial sampai ungu, dengan tangkai daun dewasa (sifatDn10) berwarna ungu. Klon pada kuadran III yaitu B9, BR5 dan TL8 mempunyai karakteristik morfologi yang kuat pada warna daging ungu tua (SifatUb6) berkaitan dengan antosianin dengan intensitas pekat (SifatUb8), kulit umbi berwarna merah keunguan (SifatUb3), helai daun berwarna hijau dengan tulang daun atas ungu (SifatDn8), serta batang berwarna ungu (sifatBt5). Klon BSepa-U, AHT-U, M3, TL1 dan varietas Antin 2 pada kuadran IV dengan karakteristik pada warna daging umbi yang berkaitan dengan antosianin (sifatUb6) dengan intensitas pekat (SifatUb8), korteks berwarna ungu (SifatUb11), warna kulit umbi ungu tua dan merah keunguan (SifatUb3), helai daun hijau (sifatDn8), serta warna batang hijau dengan spot ungu (SifatBt5). Hasil ini menunjukkan bahwa klon-klon berkelompok berdasarkan karakteristik morfologi tertentu yang diperlihatkan melalui arah vektor dengan objek pada suatu kuadran. Menurut Setiawati et al. (2013), aksesi-aksesi ubi jalar pada kuadran yang sama menunjukkan hubungan kekerabatan yang dekat, sebaliknya jika berada pada kuadran yang berbeda dengan sudut $90^{\circ}$ maka mempunyai hubungan kekerabatan yang jauh.

Tabel 4. Vektor ciri dari 14 karakter pada tiga komponen utama

\begin{tabular}{lllcc}
\hline \multirow{2}{*}{ No. } & \multicolumn{1}{c}{ Karakter morfologi ubi jalar } & \multicolumn{2}{c}{ Komponen } & KU3 \\
\cline { 3 - 5 } 1 & Warna tulang daun permukaan bawah (Dn5) & 0.897 & -0.200 \\
2 & Warna tulang daun permukaan atas (Dn6) & 0.853 & 0.206 & -0.079 \\
3 & Warna tangkai daun dewasa (Dn10) & 0.750 & 0.059 & 0.194 \\
4 & Warna helaian daun dewasa (Dn8) & 0.729 & 0.250 & -0.210 \\
5 & Warna korteks umbi (Ub11) & -0.648 & 0.355 & 0.288 \\
6 & Pigmentasi pada batang utama (Bt5) & 0.605 & 0.519 & 0.403 \\
7 & Warna daging umbi (pigmen karoten) (Ub7) & 0.051 & 0.311 & -0.054 \\
8 & Warna daging umbi (pigmen antosianin) (Ub6) & -0.199 & -0.906 & 0.337 \\
9 & Warna kulit umbi (Ub3) & -0.104 & 0.861 & -0.055 \\
10 & Intensitas warna daging umbi (Ub8) & -0.239 & 0.795 & 0.071 \\
11 & Tipe tanaman (Bt2) & 0.305 & 0.056 & -0.732 \\
12 & Intensitas rambut pada ujung batang (Bt7) & 0.073 & 0.373 & -0.731 \\
13 & Pola lekuk daun (Dn2) & 0.366 & -0.354 & 0.683 \\
14 & Bentuk Daun (Dn1) & 0.502 & 0.018 & 0.607 \\
\hline
\end{tabular}


Klon B65, B5 dan H1 kurang beragam pada 12 karakter morfologi, diperlihatkan melalui posisinya yang dekat dengan titik asal (Gambar 2B). Suatu objek berada sekitar titik asal menunjukkan bahwa objek tersebut mempunyai keseragaman pada semua vektor, sedangkan objek yang semakin jauh dari titik asal semakin beragam dan menunjukkan spesifikasi dengan vektor tertentu.
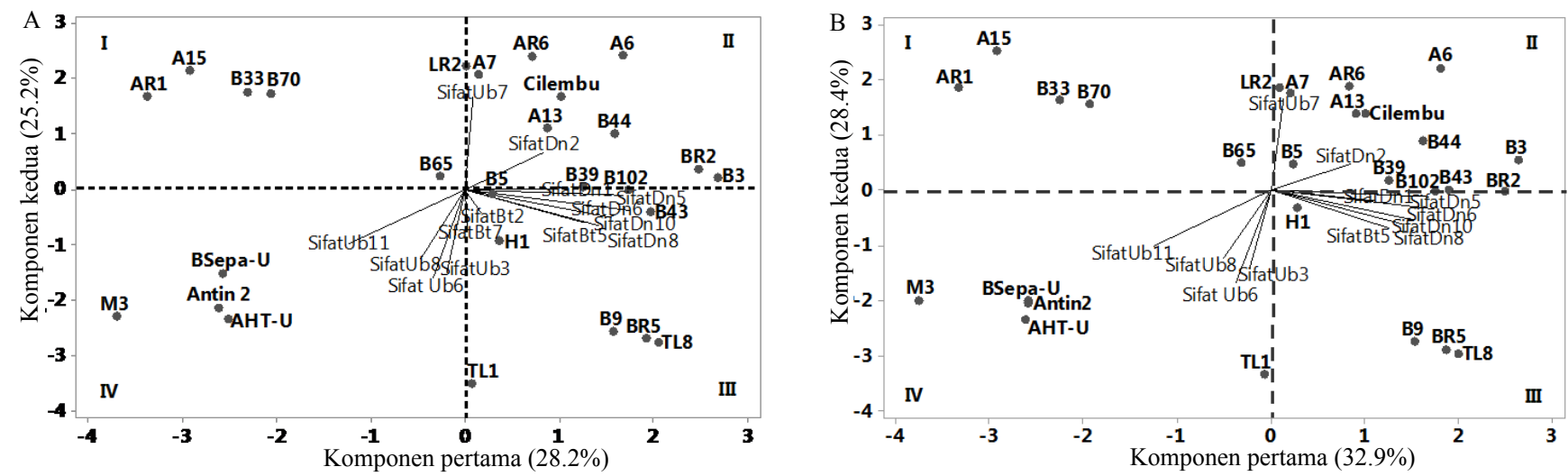

Gambar 2. Biplot 27 klon ubi jalar berdasarkan karakteristik morfologi. Empat belas karakter morfologi dengan keragaman 53.40\% (A), dan dua belas karakter dengan keragaman $61.30 \%$ (B)

\section{KESIMPULAN}

Dua puluh delapan klon ubi jalar berkelompok pada dua gerombol dan 14 sub gerombol. Tiga sub gerombol mempunyai koefisien kemiripan yang tinggi yaitu 0.68-0.96. Sebelas kelompok klon menunjukkan koefisien kemiripan rendah yaitu 0.41-0.52. Empat belas karakter morfologi tereduksi dalam 3 komponen utama dengan keragaman kumulatif yaitu $70.79 \%$, dan 14 karakter morfologi tersebut yang menentukan keragaman 27 klon ubi jalar. Hasil analisis biplot, dua belas karakter berkontribusi terhadap keragaman kumulatif sebesar $61.30 \%$. Dua belas karakter tersebut berpengaruh lemah terhadap empat klon ubi jalar yang berada pada kuadran I. Karakteristik utama dari 12 klon pada kuadran II yaitu daging umbi berwarna oranye, kuning dan putih, tiga klon pada kuadran III berwarna daging ungu tua, lima klon pada kuadran IV mempunyai daging umbi dan korteks berwarna ungu, sedangkan tiga klon yaitu B65, B5 dan $\mathrm{H} 1$ cenderung mirip pada 12 karakter.

\section{UCAPAN TERIMA KASIH}

Kami menyampaikan terima kasih kepada Kementerian Riset, Teknologi dan Pendidikan Tinggi melalui Universitas Pattimura yang mendanai penelitian ini pada Skim Penelitian Produk Terapan tahun 2017 dengan judul "Produksi KlonKlon Ubi Jalar Harapan Asal Provinsi Maluku Berdasarkan Potensi Hasil, Adaptabilitas dan Stabilitas pada Lingkungan Lokal”.

\section{DAFTAR PUSTAKA}

Afuape, S.O., P.I. Okocha, D. Njoku. 2011. Multivariate assessment of the agromorphological variability and yield components among sweet potato (Ipomoea batatas (L.) Lam) landraces. Afr. J. Plant Sci. 5:123132.

Aghaee, M., R. Mohammadi, S. Nobavati. 2010. Agromorphological characterization of durum wheat accessions using pattern analysis. AJCS. 4:505-514.

CIP/AVRDC/IBPGR. 1991. Descriptors for Sweet Potato. In Huamán, Z. (Ed.), International Board for Plant Genetic Resources, Rome, Italy.

Koij, F.S., J. Saba. 2015. Using cluster analysis and principal component analysis to group lines and determine important traits in white bean. Procedia Environ. Sci. 29:38-40.

Laurie, S.M., F.J. Calitz, P.O. Adebola, A. Lezar. 2013. Characterization and evaluation of South African sweet potato (Ipomoea batatas (L.) LAM) land races. South Afr. J. Bot. 85:10-16.

Maquia, I., I. Muocha, A. Naico, N. Martins, M. Gouveia, I. Andrade, L.F. Goalao, A.I. Ribeiro. 2013. Molecular, morphological and agronomic characterization of the sweet potato (Ipomoea batatas L.) germplasm collection from Mozambique: genotype selection for drought prone regions. South Afr. J. Bot. 88:142151.

Moulin, M.M., S. Rodrigues, L.S.A. Goncalves, C.V. Sudre, M.H. dos Santos, J.R.P. da Silva. 2012. Collection and morphological characterization of sweet potato landraces in north of Rio de Janeiro state. Hort. Brasileira. 30:286-292. 
Raharjo, S.H.T., H. Hetharie, G.H. Augustyn, M. Pesireron. 2014. Keragaman ubi kayu dan ubi jalar di Seram Bagian Barat dan peluang pemanfaatannya untuk ketahanan pangan dan industri. hal. 73-102. Dalam W. Girsang., R.M. Osok (Eds.). Percepatan Pembangunan Ekonomi Berbasis Hasil Kajian Pertanian dan Perikanan di Provinsi Maluku. Pensil Komunika, Yogyakarta. ISBN : 978-602-71915-2-5.

Roullier, C., R. Kambouo, J. Paofa, D. McKey, V. Lebot. 2013. On the origin of sweet potato (Ipomoea batatas (L.) Lam.) genetic diversity in New Guinea, a secondary centre of diversity. Heredity. 110:594604.

Setiawati, T., Karyono, T. Supriatun, A. Karuniawan. 2013. Analisis keragaman genetik kerabat liar ubi jalar asal Citatah sebagai sumber gen untuk merakit ubi jalar unggul berdasarkan karakter morfologi. Biodjati. 3:14-20.
Su, W., Y. Liu, L. Wang, S. Chai, C. Jiao, X. Yang. 2016. Phenotypic variation analysis of sweet potato germplasm resources from different agro-climate zones in the world. AJEA. 13:1-13.

Tairo, F., E. Mneney, A. Kullaya. 2008. Morphological and agronomical characterization of sweet potato [Ipomoea batatas (L.) Lam.] germplasm collection from Tanzania. Afr. J. Plant Sci. 2:077-085.

Undang, M. Syukur, Sobir. 2015. Identifikasi spesies cabai rawit (Capsicum spp.) berdasarkan daya silang dan karakter morfologi. J. Agron. Indonesia 43:118-125.

Yada, B., P. Tukamuhabwa, A. Alajo, R.O.M. Mwanga. 2010. Morphological characterization of Ugandan sweetpotato germplasm. Crop Sci. 50:2364-2371. 